MALLOMO: Journal of Community Service

https://jurnal.umsrappang.ac.id/mallomo/index

Vol 1, No, 1, Desember 2020, pp 1-14

\title{
Menelusuri dan MembandingkanTransportasi Publik Berbasis Rel antara Kuala Lumpur dengan Jakarta
}

\author{
Muhammad Rais Rahmat Razak, Jamaluddin Ahmad \\ ${ }^{1}$ Ilmu Pemerintahan, Universitas Muhammadiyah Sidenreng Rappang \\ mraisrahmat@umsrappang.ac.id \\ 2IImu Administrasi Publik, Universitas Muhammadiyah Sidenreng Rappang
}

Abstract. Management of public transportation in Indonesia, especially Jakarta, as the capital city of the country, is lagging behind the developed countries in the world and lagging behind seeing progress in Southeast Asian countries, thus directly affecting the low competitiveness of investment and the level of national tourist destinations. This paper aims to explore rail-based public transportation in Kuala Lumpur and compare with conditions in Jakarta. The method used is a descriptive analysis by tracing public transportation through comparative study activities in students of the Master of Public Administration. The results of a comparative study show that the public transportation system in Kuala lumpur especially rail-based transportation is still better than Jakarta. This is because the mode of transportation has been integrated as the Klang Valley Integrated Rail Transit, including; KL Monorail, LRT (light rapid transit), KTM Commuter, KLIA Express / KLIA Transit, and MRT (Mass Rapid Transit).

Abstrak. Pengelolaan transportasi publikdi Indonesia khususnya Jakarta sebagai ibu kota negara termasuk tertinggal dibandingkan dengan negara maju di dunia dan ketinggalan jika melihat kemajuan di negara-negara Asia Tenggara sehingga berpengaruh langsung pada rendahnya daya saing investasi dan tingkat destinasi wisata nasional. Tulisan ini bertujuan untuk menelusuri transportasi publik berbasis rel di Kuala Lumpur dan membandingkan dengan kondisi yang ada di Jakarta.Metode yang digunakan adalah dengan analisis deskriftif dengan menelusuri transportasi public melalui kegiatan pendampingan studi banding pada mahasiswa Magister Administrasi Publik. Hasil studi banding menunjukkan bahwa system transportasi public di Kuala lumpur khususnya transportasi berbasis rel masih lebih baik dibandingkan dengan Jakarta. Hal ini karena moda transportasi telah terintegrasi sebagai Klang Valley Integrated Rail Transit, meliputi; KL Monorail, LRT (light rapid transit), KTM Komuter, KLIA Ekspres / KLIA Transit, dan MRT (Mass Rapid Transit). 


\section{Keywords:}

Public

transportation;

Jakarta;

Kuala lumpur.
Coresponden author:

Email: mraisrahmat@umsrappang.ac.id

artikel dengan akses terbuka di bawah lisensi CC BY $-4.0^{\mathrm{gr}}$

\section{PENDAHULUAN}

Walikota Quangzhou China, Wan Qingliang pada tahun 2011 berhasil menata kotanya dengan membuat system angkutan umum modern, Bus Rapid Transit (BRT) bersinergi dengan Mass Rapid Transit (MRT) guna mengurangi kemacetan dan membantu pergerakan manusia. Dengan penduduk 11 Juta yang tidak jauh berbeda dengan DKI Jakarta yang kurang lebih 10 juta jiwa berhasil memperbaiki system transportasi publiknya(Pambagio, 2013).Kuala lumpur dengan penduduk 1,6 juta jiwa juga dapat mengurangi kemacetan dengan membangun moda transportasi yang berbasis rel serta dapat mewujudkan konektivitas antar moda transportasi(Tech, 2018). Di Jakarta Sistem pertransportasian selalu menjadi issu menarik dan bahkan menjadi topic perdebatan seksi dalam setiap perhelatan kontektasi pemilihan kepala daerah langsung, karena issue transportasi massal bersentuhan langsung dengan masyarakat umum. Indonesia sebagai anggota utama dalam perkumpulan negara-negara asia tenggara (Asean) belum banyak memberikan contoh pengelolaan system transportasi yang baik. Justru negara-negara seperti Singapura dan Malaysia lebih dulu menata system transportasinya. Maka tidak mengherankan jika kedua negara ini lebih diminati oleh wisatawan asing dibandingkan dengan Indonesia.Pada Rilis BBC News tahun 2017 diketahui bahwa, Kuala lumpur menempati peringkat empat lebih baik dari Jakarta yang peringkat 37 dari 51 kota terbaik di dunia dalam hal kota impian bagi para ekspatriat.Pemeringkatan tersebut berdasarkan sejumlah kriteria, seperti kualitas dan biaya hidup yang terdiri dari, biaya transportasi, sewa rumah, ketersediaan dan suasana kerja serta kemudahan untuk menetap.Peringkat teratas ditempati Kota Manama di Bahrain, yang oleh para ekspatriat dikatakan mudah sekali untuk menetap. Sekitar $92 \%$ responden mengatakan bermukim di Manama tak terlalu sulit meski tidak menguasai bahasa lokal, bahasa Arab(Susilo, 2017).Perkembangan dua puluh tahun terakhir sejak gerakan reformasi tahun 1998 di Indonesia yang menjadi tonggak pembangunan bangsa berbasis tuntutan public ternyata belum mampu membawa pembangunan infrastruktur berorientasi public, sebagai contoh system transportasi masih setengah hati, moda transportasi belum terkoneksi dengan baik antara moda satu dengan moda transportasi lainnya sehingga berdampak pada tingginya biaya transportasi. Sedangkan Kuala Lumpur Malaysia melaju dengan pengembangan system transportasi berbasis rel melalui Klang Valley Integrated Rail Transit. di Jakarta public belum banyak merasakan kenyamanan dan kemudahan karena moda transportasi seperti bus, angkutan kota belum terkoneksi baik dengan commuter line, MRT dan busway. Dalam hal Pengawasan emisi gas buang, kelaikan kendaraan massal tidak berjalan dengan baik. Ssystem KIR atau (bahasa Belanda = KEUR) yang berarti, kumpulan rangkaian kegiatan untuk melakukan uji kendaraan bermotor sebagai tanda bahwa kendaraan tersebut layak digunakan secara teknis di jalan raya, khususnya bagi kendaraan yang membawa angkutan penumpang dan barang(Tech, 2018). Belum dapat memastikan, bahwa hanya bus atau kendaraan massal yang layak beroperasi di jalan. Masih ditemukan banyak bus yang sudah berumur lebih 20 tahun beroperasi di jalan-jalan dengan kondisi yang jauh dari kenyamanan.Konstitusi undang-undang nomor 22 tahun 2009 pasal 48 ayat 1 dan 2 dengan tegas menyatakan bahwa, setiap kendaraan bermotor yang dioperasikan di jalan harus memenuhi persyaratan teknis dan laik jalan, persyaratan yang dimaksud minimal ditentukan oleh kinerja minimal kendaraan bermotor yang diukur sekurang-kurangnya terdiri atas; emisi gas buang, kebisingan suara, dan kesesuaian daya mesin penggerak terhadap berat kendaraan. Ketidak konsekuenan pemerintah dalam menegakkan peraturan berakibat pada meningkatnya tingkat pencemaran udara atau polusi di kota-kota besar di 
Indonesia. Upaya para kepala daerah dalam menata system transportasi perlu terus didorong agar terbangun system yang mengedepankan prinsip-prinsip patisipatif, efisien dan terpadu seperti yang diamanatkan dalam undang-undang nomor 22 tahun 2009 pasal 2 yang menyatakan bahwa, lalulintas dan angkutan jalan diselenggarakan dengan memperhatikan asas transparan, akuntabel, berkelanjutan, partisipatif, efesien dan efektif, seimbang, terpadu dan mandiri.Implementasi di lapangan menunjukkan, bahwa transportasi public di negeri ini belum mencapai sasaran dan pemerintah masih terus melakukan uji coba dan kajian mendalam terkait system transportasi yang cocok dengan kondisi Indonesia.(Razak, M.R.R ; Dahong, Mansyur ; Ahmad, J; Dema, H \& Mustanir, 2019), (Mustanir, Ahmad;Razak, 2017)

\section{Transportasi Publik}

Pemerintah berkewajiban untuk melakukan perbaikan terhadap tata kelola pemerintahan yang baik atau biasa disebut dengangood governance, termasuk di dalamnya adalah perbaikan layanan public (Razak, M.R.R;Harfiah, 2018). Pelayanan public pada dasarnya menyangkut aspek kehidupan yang sangat luas dan juga merupakan salah satu unsur yang mendorong perbaikan kualitas layanan transportasi public (Fadli; Madani, Muhlis; Idris, 2014). Transportasi umumjuga dikenal sebagai transportasi publik atau transportasi massal,adalah layanan angkutan penumpang oleh sistem perjalanan kelompok yang tersedia untuk digunakan oleh masyarakat umum, biasanya dikelola sesuai jadwal, dioperasikan pada rute yang ditetapkan, dan dikenakan biaya untuk setiap perjalanan(Schefer, 2019). Di Malaysia khususnya Kuala lumpur, transportasi public dikenal transportasi berbasis rel seperti MRT, LRT KL Monorail, Komuter Line, dan transportasi berbasis bus seperti Rapid KL dan Go KL sedangkan di Jakarta dikenal seperti busway oleh trans Jakarta, bus mayasari bakti, PPD, Metro mini dan Kopaja. Berbasis rel ada comuter line, MRT (Moda Raya Transportasi) sejauh 16 KM yangpada bulan april tahun 2019 telah di beroperasi secara komersial. Kemudian menunggu penyelesaian pembangunan LRT (Light Rapid Transit/Lintas Rel Terpadu) yang ditargetkan dibangun sejauh $44 \mathrm{KM}$ dan direncanakan selesai pada tahun 2020(Prabowo, 2019). Dalam PeraturanPresiden (PP) Nomor 98 Tahun 2015 tentang Percepatan Penyelenggaraan Kereta Api Ringan. Menurut rencana proyek LRT akan dibangun hingga sepanjang 82 kilometer. LRT Jabodebek sendiri terdiri atas tiga relasi yaitu Cawang-Cibubur, Cawang-KuninganDukuh Atas, dan Cawang-Bekasi Timur.Sedangkan relasi berikutnya yang akan dibangun pada fase kedua sepanjang 38 kilometer, menjangkau hingga wilayah Bogor. Pembangunan LRT, MRT kedepan akan terintegrasi dengan Kereta Bandara Soekarno-Hatta, Commuter Line, dan Bus Transjakarta yang sampai sekarang ini dirasakan masih kurang(Prabowo, 2019).

\section{Kuala Lumpur dan Jakarta}

Kuala lumpur dan Jakarta, adalah ibukota negara Malaysia dan Indonesia, dan bila dilihat dari aspek geografis, lingkungan, dan sosio - kultural, keduanya memiliki kemiripan (Dinisan, 2018). Namun dalam hal pengelolaan transportasi public keduanya mempunyai perbedaan.Perkembangan pada satu tahun terakhir ini menunjukkan Jakarta sedang berbenah dengan membangun moda transportasi MRT dan LRT yang terintegrasi dengan BRT.Pada transportasi berbasis bus, berbeda dengan Malaysia Indonesia lewat transjakarta berhasil mengurangi kemacetan dengan menyediakan transportasi public yang menawarkan kenyamanan dan ketepatan waktu.Program ini dimulai pada pemerintahan Gubernur Sutiyoso yang memutuskan untuk meniru sistem BRT Bogota dengan koridor pertama Blok M-Kota, dari Selatan ke Utara melewati jalan protokol Sudirman-Thamrin. PT Transportasi Jakarta yang dikenal dengan " Transjakarta" menawarkan konsep "murah meriah" sebagai solusi. Dengan memanfaatkan jalan yang sudah ada dan konstruksi simpel, Koridor I Blok MKota sepanjang 12,9 kilometer yang menhhabiskan 29 juta dollar AS. Rute Transjakarta hingga kini 


\section{4 | MALLOMO: Journal of Community Service}

terus dikembangkan. Saat ini sudah tersedia lebih dari 125 rute, 2.000 armada bis, dan lebih dari 650.000 penumpang setiap harinya. Lebih dari itu, komitmen politik yang kuat juga mendukung ketersediaan infrastruktur dan subsidi tarif, sehingga harga tiket Transjakarta menjadi sangat terjangkau. Harga tiket yang hanya senilai Rp 3.500 belum berubah sejak 14 tahun lalu. Sementara, MRT di Kuala Lumpur hanya mengangkut 132.000 orang setiap harinya)(Sodikin, 2018).

\section{Menelusuri dan Membandingkan}

"Pepatah lama menyatakan, tak kenal maka tak sayang". Belajar pelayanan public kalau hanya di kelas dan tidak dicoba untuk melihat langsung ke lapangan maka akan kurang mantap. Demikian penegasan Jamaluddin Ahmad Rektor Universitas Muhammadiyah Rappang pada setiap diskusi di Kuala lumpur. Hal ini kemudian memotivasi Dosen untuk membawa mahasiswanya ke negeri jiran guna melakukan penelusuran dan membandingkan layanan public khususnya layanan transportasi public di Malaysia.Kegiatan inifocus pada studi banding dan melihat best practice layanan public yang ada di Malaysia."Mereka harus melihat langsung pelayanan publik yang efisien dan efektif, tidak hanya sekedar teori dan gagasan, yang dipelajari selama berada di jenjang perkuliahan(Amiruddin, 2019), (Razak, 2018). Sebagai observasi awal adalah temuan dan kesimpulan pada saat mendampingi mahasiswa dalam kegiatan study banding akhir 2016 kemudian dilanjutkan dengan mendampingi kegiatan magang internasional di Malaysia pada bulan Mei 2017,beberapa poin menjadi kesimpulan dan temuan adalah:

- System transportasi public yang ada di Kuala Lumpur termasuk dalam kategori modern serta terintegrasi dan terkoneksi baik antara satu moda transportasi dengan moda transportasi lainnya sebagai Klang Valley Integrated Rail Transit, meliputi; KL Monorail, LRT (light rapid transit), KTM Komuter, KLIA Ekspres / KLIA Transit, dan MRT (Mass Rapid Transit).

- Pengelolaan transportasi dikelola dengan professional dan mengutamakan konsep pelayanan yang nyaman dan tepat waktu dengan system penjadwalan yang ketat

- Ticketing menggunakan ITdan pembelian tiket lewat "vanding machine" yang dapat dioperasikan dengan mudah.

- Pelyanan transportasi public mengedepankan kenyamanan dan keamanan

- Ada Kemudahan akses

Untuk menindak lanjuti hasil temuan pada kegiatan bench marking, maka akhir tahun 2017, awal 2018 dan tahun 2019 kembali melakukan pendampingan mahasiswa ke Malaysia dan focus pada penelusuran pada system transportasi public berbasis rel(Amiruddin, 2019).

\section{Metode}

Tulisan ini menggunakan analisis deskriftif komparatif dengan pendekatan kualitatif yaitu membandingkan keberadaan satu variable atau lebih pada dua atau lebih sample yang berbeda, atau pada waktu yang berbeda (Sugiyono, 2017),(Ahmad, 2015). Dengan cara mendeskripsikan atau memberikan gambaran tentang fenomena dan fakta-fakta di lapangan terkait dengan beberapa variable system transportasi publik yang digunakan di Jakarta dengan Kuala Lumpur. Nara sumber adalah mahasiswa semester akhir administrasi public yang didampingi dalam kegiatan studi banding pasca sarjana Universitas Muhammadiyah Sidenreng Rappang yang akan menelusuri best practice pelayanan public di Malaysia. Tulisan ini mengambil focus pada pelayanan public system transformasi berbasis rel di Kuala lumpur dibandingkan dengan Jakarta. Pemilihan Kuala lumpur dan Jakarta sebagai locus perbandingan karena kedua ibukota ini memiliki banyak kesamaan dibandingkan dengan ibukota negara yang lain, sehingga dalam menggambarkan dan membandingkan diharapkan dapat memberikan pencerahan.

Untuk membandingkan dipilih nara sumber dari mahasiswa yang pernah merasakan system transportasi Jakarta dan Kuala lumpur, kemudian dibahas dalam forum diskusi. Hasil penelitian 
kemudian diolah dan dipresentasikan pada hari terakhir studi banding.Untuk menelusuri dan membandingkan transportasi public, dilakukan dengan menggunakan indicator dari mutu pelyanan public menurut parasurahman yaitu; 1) kehandalan (realibility), 2) empati (emphaty) 3) berwujud (tangible) 4).Ketanggapan (responsiveness) dan kelima jaminan kepastian (assurance). Hasil penelusuran mahasiswa kemudian didiskusikan dan disimpulkan dalam bentuk temuan sementara.

\section{Hasil Dan Pembahasan}

Membawa mahasiswa mengenal pelayanan publik di Malaysia khususnya di Kuala Lumpur merupakan salah satu tugas pengabdian yang menarik karena dosen dapat menjelaskan secara langsung kelebihan sistem transportasi publik yang dimiliki Kuala lumpur. Mengurangi kemacetan dengan membangun transportasi publik yang terkoneksi dapat mengurangi pemakaian kendaraan pribadi dan dapat menggerakkan perekonomian, karena warga dapat mengunjungi pusat-pusat pertumbuhan ekonomi dengan biaya terjangkau. Dan para ekspatriat dapat menikmati destinasi wisata dengan mudah dan nyaman.

\section{Konektivitas moda Transportasi}

Salah satu kelebihan yang dimiliki oleh Kuala Lumpur dibandingkan dengan Jakarta adalah kenyamanan warga asing dalam menggunakan transportasi public untuk mengunjungi tempattempat wisata dan pusat perbelanjaan. Moda transportasi terkoneksi dengan baik dan para pengguna memiliki informasi terbuka dan mudah di akses. Hal ini sejalan dengan tujuan studi banding yang dilakukan mahasiswa semester akhi pasca administrasi publik, untuk melihat best practice dari system transportasi publik di Malaysia. Prinsip-prinsip layanan publik menurut para surahman digunakan sebagai indikator untuk membandingkan transportasi publik di Jakarta dan Kuala lumpur. 


\section{SPAD Greater KL / Klang Valley Integrated Transit Map}

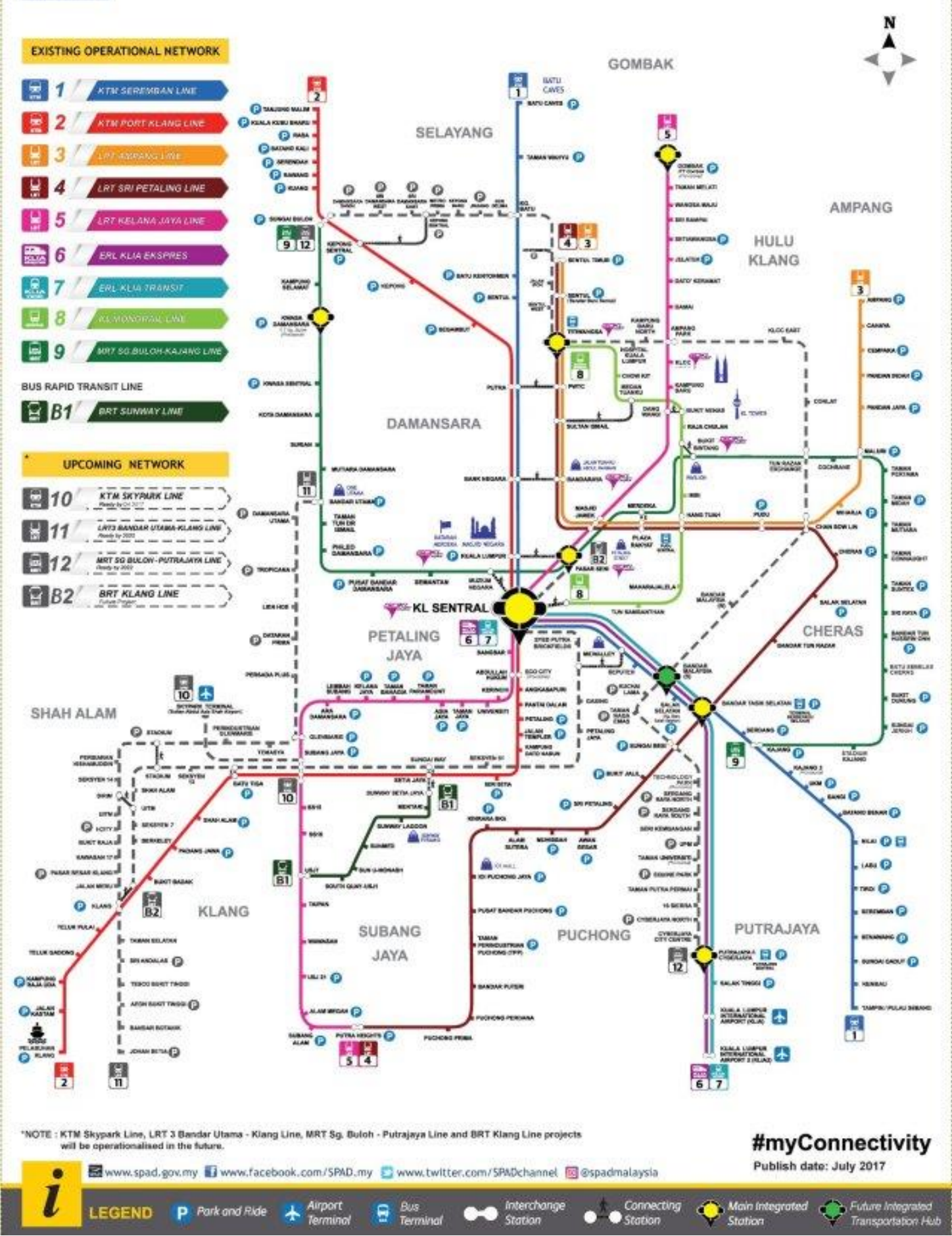

Gambar 1. Peta konektifitas Jalur transportasi berbasis rel di Kuala Lumpur.(Kumparan.com, 2017)

Terminal utama dari konektivitas transportasi ada di terminal utama KL sentral, jadi di mana pun kita berada untuk merasakan interkoneksitas antar moda dapat langsung ke Terminal utama KL sentral, di sana ada berbagai jenis moda transportasi yang dapat dipilih sesuai dengan tujuan yang telah direncanakan. Dengan bantuan peta diatas akan memudahkan calon penumpang dalam menentukan pilihan moda transportasi yang dipilih. Berbeda dengan interkoneksi moda transportasi di Jakarta. Sederhana dan banyak stasiun belum tersambung dengan moda transportasi lain. 


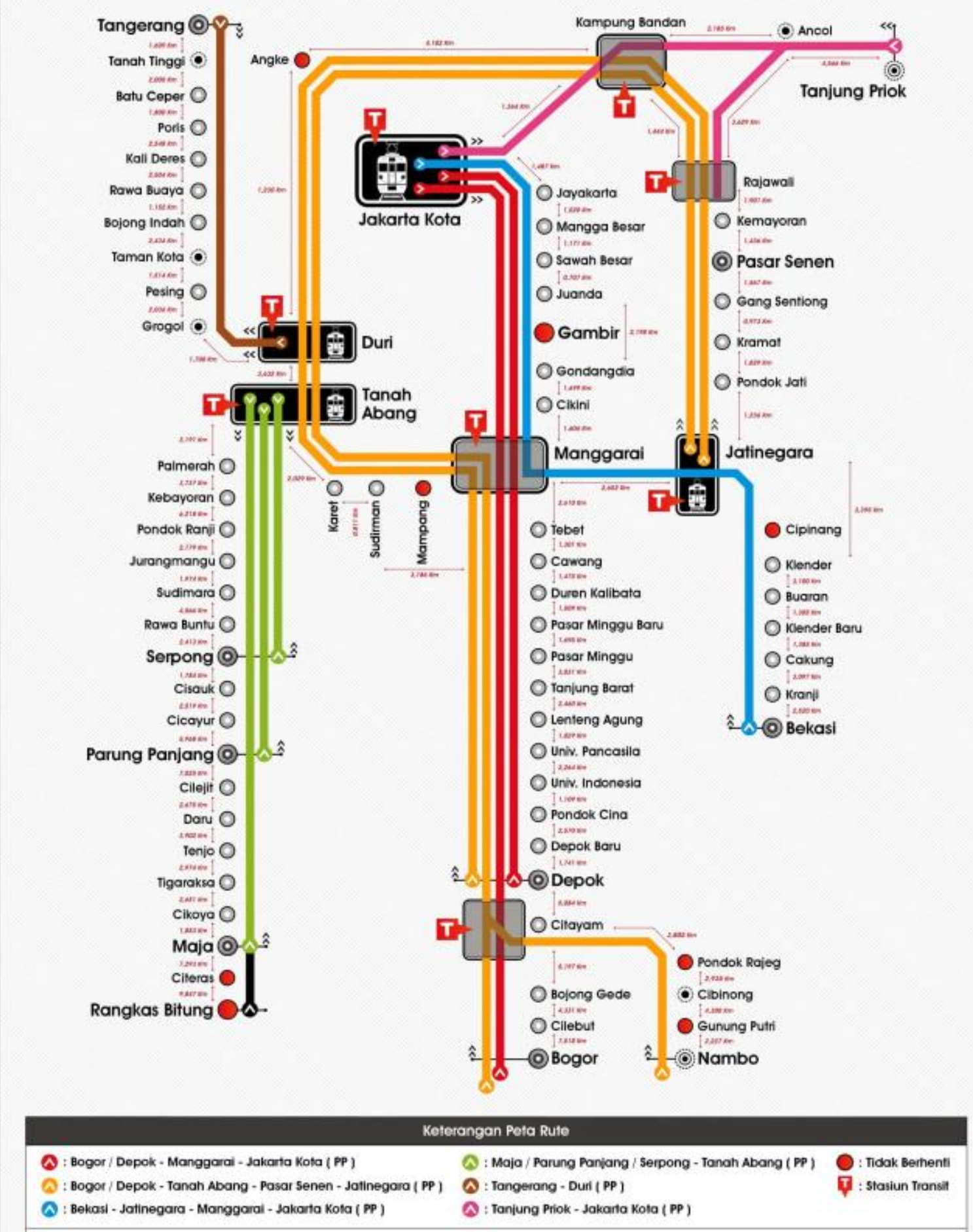

Gambar 2. Peta jalur comuter lain jabodetabek(Kumparan.com, 2017)

Untuk menelusuri system transportasi public di Kuala lumpur, dapat dimulai dengan memahami dua jenis transportasi darat yang ada, yitu; transportasi berbasis rel terdiri darii KL Monorail, LRT (light rapid transit), KTM Komuter, KLIA Ekspres / KLIA Transit, dan MRT (Mass Rapid Transit). Kemudian transportasi berbasis bus terdiri dari Rapid-KL dan Go-KL.

\section{Transportasi berbasis rel}

Untuk menjelajahi Kuala lumpur dapat dengan mudah tanpa harus menggunakan jasa guide atau pemandu wisata, namun terlebih dahulu harus bisa memahami dengan baik manajemen transportasi yang ada di Kuala lumpur. Secara umum, moda transportasi ini telah terintegrasi menjadi satu system transportasi public yang dikenal dengan Klang Valley Integrated Rail 


\section{8 | MALLOMO: Journal of Community Service}

Transit.terdiri dari MRT (Mass Rapid Transit), KLIA Ekspres / KLIA Transit, LRT (light rapid transit), , KTM Komuter, KL Monorail, dan Lalu. Untuk menelusuri perbedaan dari 5 moda transportasi tersebut, mahasiswa diajak untuk mencoba dan merasakan sendiri menikmati kenyamanan transportasi public di Kuala lumpur.

\section{Commuter Line Kuala Lumpur dan Jakarta}

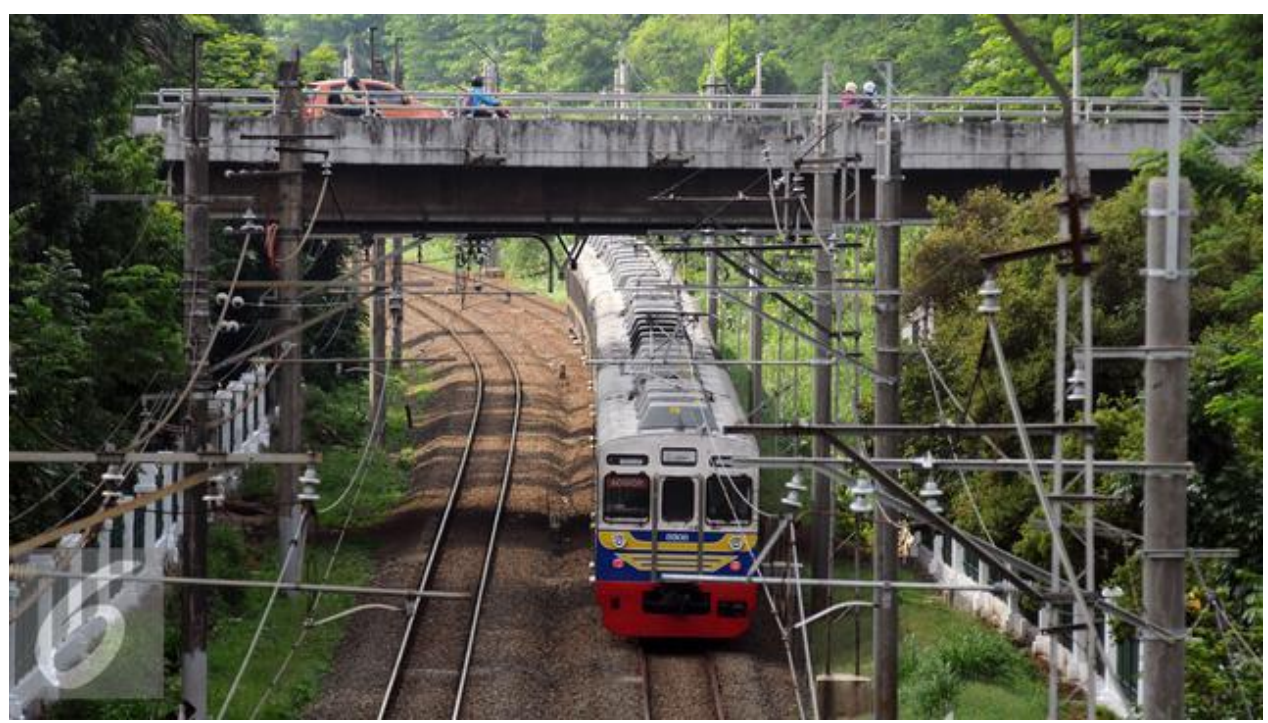

Gambar 3 Commuter line di Jakarta(Kumparan.com, 2017)

Commuter Line, MRT yang sekarang sudah beroperasi di Jakarta dan LRT yang masih dalam pembangunan, ketiganya sama-sama digerakan oleh aliran listrik dari bagian atas. Seperti halnya di Jakarta, kereta listrik adalah salah satu moda transportasi andalan di Kuala Lumpur. Terdapat tiga jenis kereta yang melayani penumpang dalam kota. Yaitu rapid rail, commuter rail dan monorail.Ketiga jenis kereta tersebut memiliki jalur dan tujuan yang berbeda, tetapi ketiganya terintegrasi lewat stasiun Interchange.Seperti contohnya rapid rail.Biasa juga disebut dengan RapidKL, memiliki dua jalur utama, yaitu Ampang Line dan Kelana Jaya Line yang merupakan jalur metro paling penting di Kuala Lumpur karena menghubungnkan pusat kota dengan Subang Jaya, Petaling Jaya dan daerah Gombak, keduanya membelah kota Kuala Lumpur dari utara ke selatan. Selain Rapid rail, Kuala Lumpur juga menggunakan Commuter Rail.Sistem Commuter Rail dikendalikan oleh dua operator, Keretapi Tanah Melayu dan Express Rail Link.Ada 4 (empat) jalur commuter di Kuala Lumpu, yaitu Port Klang Line, Seramban Line, Tanjung Malim Shuttle Service dan KLIA Transit.Keempat jalur itu terhubung di KL Sentral, hub transportasi terbesar di Asia Tenggara.Dengan jumlah 29 stasiun, sistem ini memiliki panjang rute mencapai 27 kilometer.Yang terakhir adalah, Monorail.Monorail adalah moda tranportasi berbasis rel yang hanya memiliki satu rel. Tempat duduk di Monorail ditata saling membelakangi. Monorail memiliki 11 stasiun yang membentang sepanjang 8,6 KM. Jalur ini juga menghubungkan KL Sentral dengan stasiun Titiwangsa, stasiun terdekat dari Menara Kembar Petronas berdiri.Penumpang menggunakan kartu Touch ' $\mathrm{n}$ Go untuk membayar biaya perjalanan. Kartu Touch ' $n$ Go ini juga bisa digunakan untuk moda transportasi lain di Malaysia. Sistem biaya yang dignakan adalah berbasis jarak.

Di Jakarta, Comuter line mulai dikenal sejak tahun 2008, oleh PT KCJ, sejak tahun 2011, beberapa jenis layanan diubah, kemudian 2013, commuter line di Jakarta mulai menggunakan sistem e-ticketing. Commuter line di Jakarta menghubungkan beberapa kota, seperti Bogor, Depok, Bekasi, Tangerang hingga Rangkasbitung. Terhitung ada enam rute perjalanan yang menghubungkan beberapa kota dan terdapat enam stasiun utama (Jakarta kota, Jatinegara, Manggarai, Tanah Abang, Kampung Bandan dan Duri). Selain stasiun utama tersebut, terdapat 72 stasiun di sepanjang jalur rute commuter line Jakarta. Didalam rangkaian gerbong kereta yang beroperasi itu, ada gerbong khusus wanita, biasanya dua gerbong depan kereta atau satu gerbong dibagian depan dan satu gerbong dibagian belakang. Didalam gerbong commuter line tersebut juga ada beberapa aturan, 
salah satunya adalah peraturan tentang tempat duduk untuk para penumpang. Peraturan tentang kursi prioritas yang spesial ditujukan bagi wanita hamil, penumpang yang membawa anak, lansia dan penyandang disabilitas(Nursita, 2019).

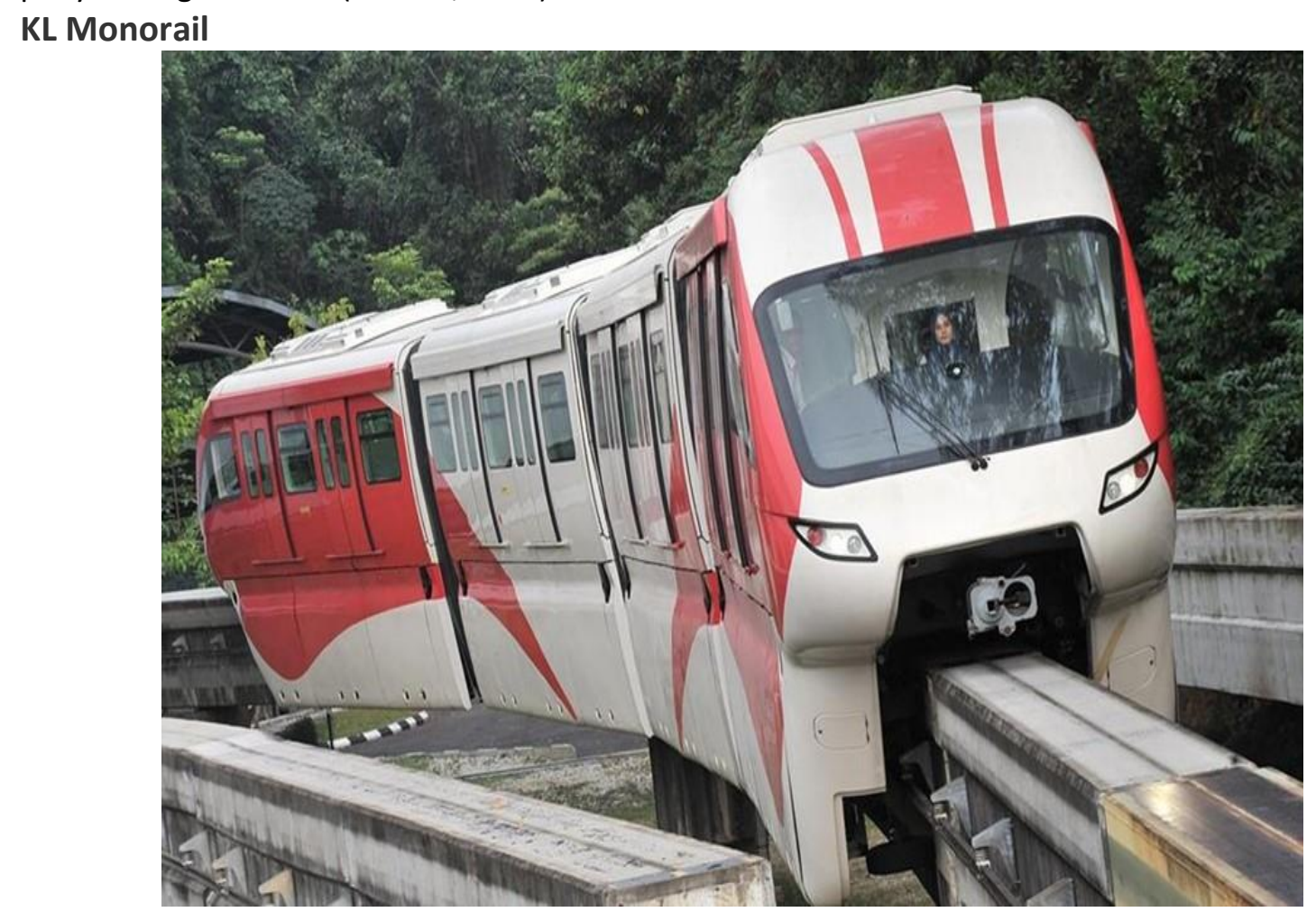

Gambar 4 Monorail di Malaysia(Kumparan, 2019)

KI Monorail merupakan moda transportasi yang menghubungkan antara KL Sentral menuju Titiwangsa.KL Monorail cukup nyaman digunakan dengan berbagai fasilitas yang tersedia.Kereta yang cukup nyaman dengan posisi saling membelakangi serta tiket yang dapat diperoleh dengan mudah.Tersedia berbagai layanan dari ATM hingga Vending Machine untuk memperoleh tiket.

Untuk rute Monorail Kuala Lumpur sendiri menghubungkan KL Sentral menuju Titiwangsa.Ada beberapa pemberhentian sebagai tempat transit ketika menggunakan moda transportasi ini. Perjalanan akan dimulai dari KL Sentral menuju Tun Sambanthan dengan melewati stasiun Bukit Bintang dan perjalanan akan berakhir di Titiwangsa.Keberadaan monorel di Indonesia terutama di Jakarta tidak diapresiasi dengan baik, proyek Monorel Jakarta yang dimulai bertepatan dengan HUT ke-477 Jakarta pada 22 Juni 2004 silam itu terbengkalai setelah pihak Omnico Singapura tidak dapat menyetor modal guna pembangunan monorel tersebut.Sempat dikabarkan bahwa monorel di Jakarta akan dibangkitkan lagi oleh investor asal Dubai, namun pada saat itu Menteri Keuangan RI Sri Mulyani (masa jabatan Kabinet SBY) menolak dengan alasan pemerintah pada saat itu tidak menjamin proyek-proyek yang tengah dibangun oleh pihak wasta.hingga saat ini rencana pembangunan Monorail di Indonesibelum memiliki titik terang. 


\section{MRT (Mass Rapid Transit)}

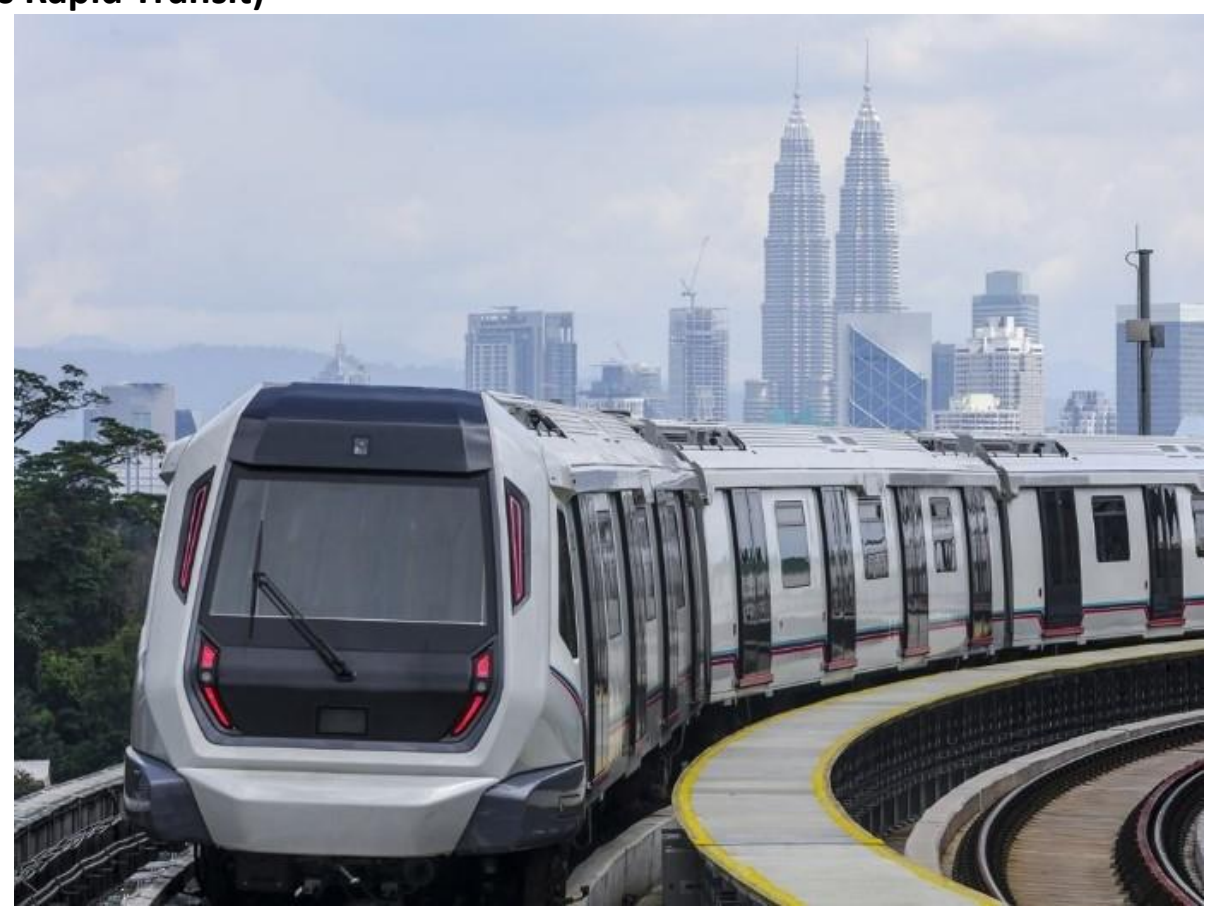

Gambar 5.MRT di Kuala Lumpur(Kumparan, 2019)

Mass Rapid Transit biasa dikenal dengan dengan MRT, Moda transportasi ini termasuk baru karena beroperasi secara komersial pada tahun 2017. MRT Malaysia melintasi 31 stasiun dan baru beroperasi satu jalur yaitu dari Sungai Buloh menuju Kajang. Saat ini pemerintah Malaysia sedang menyelesaikan MRT kedua yang diperkirakan akan selesai pada tahun 2022 dengan rute Sungai Buloh-Putrajaya. Moda transportasi ini bersinergi dengan beberapa stasiun, di antaranya, Muzium Negara yang berhubungan dengan stasiun KL Sentral, Stasiun Pasar Seni yang berhubungan dengan LRT Pasar Seni, Stasiun Bukit Bintang yang berhubungan dengan Monorail bukit bintang dan Stasiun Maluri yang berhubungan dengan Stasiun LRT Maluri. Pembelian tiket juga tidak terlalu rumit, penumpang hanya cukup membeli tiket di vending machine atau menggunakan kartu Touch and Go. Untuk mendapatkan tiket MRT di Kuala lumpur dapat diperoleh dengan mengoperasikan petunjuk yang ada di Vending Machine yang tersedia di area stasiun, tanpa harus menghubungi petugas, namun jika kurang nyaman membeli lewat mesin. Pengguna transportasi dapat langsung ke pos tiket. Tiket yang diperoleh berupa token coin ditempelkan pada area token saat memasuki pintu masuk, setelah sampai di tujuan kemudian keluar dari pintu stasiun cara memasukkan token coin kedalam lubang dan secara otomatis pintu keluar terbuka(Nursita, 2019).

Di Jakarta MRT mulai dibangun pada pemerintahan Gubernur Jokowi yang sekarang Presiden Republik Indonesia ke 7.Moda transportasi ini lebih besar dan lebih banyak penumpang yang diangkut jika dibandingkan dengan LRT.transportasi mass rapid transit ( MRT) Jakarta telah beroperasi secara komersial sejak 1 April 2019. Rute MRT Jakarta mulai dari Bundaran Hotel Indonesia (HI)-Lebak Bulus dan sebaliknya. Terdapat 13 stasiun di sepanjang rute tersebut, yang terdiri dari ujuh stasiun layang (stasiun lebak bulus grab, Fatmawati, Cipete Raya, Haji Nawi, Blok A, Blok $M$, dan ASEAN) dan enam stasiun bawah tanah terdiri dari Stasiun Senayan, Istora Mandiri, Bendungan Hilir, Setiabudi Astra, Dukuh Atas BNI, dan Bundaran HI(Sari, 2019). 


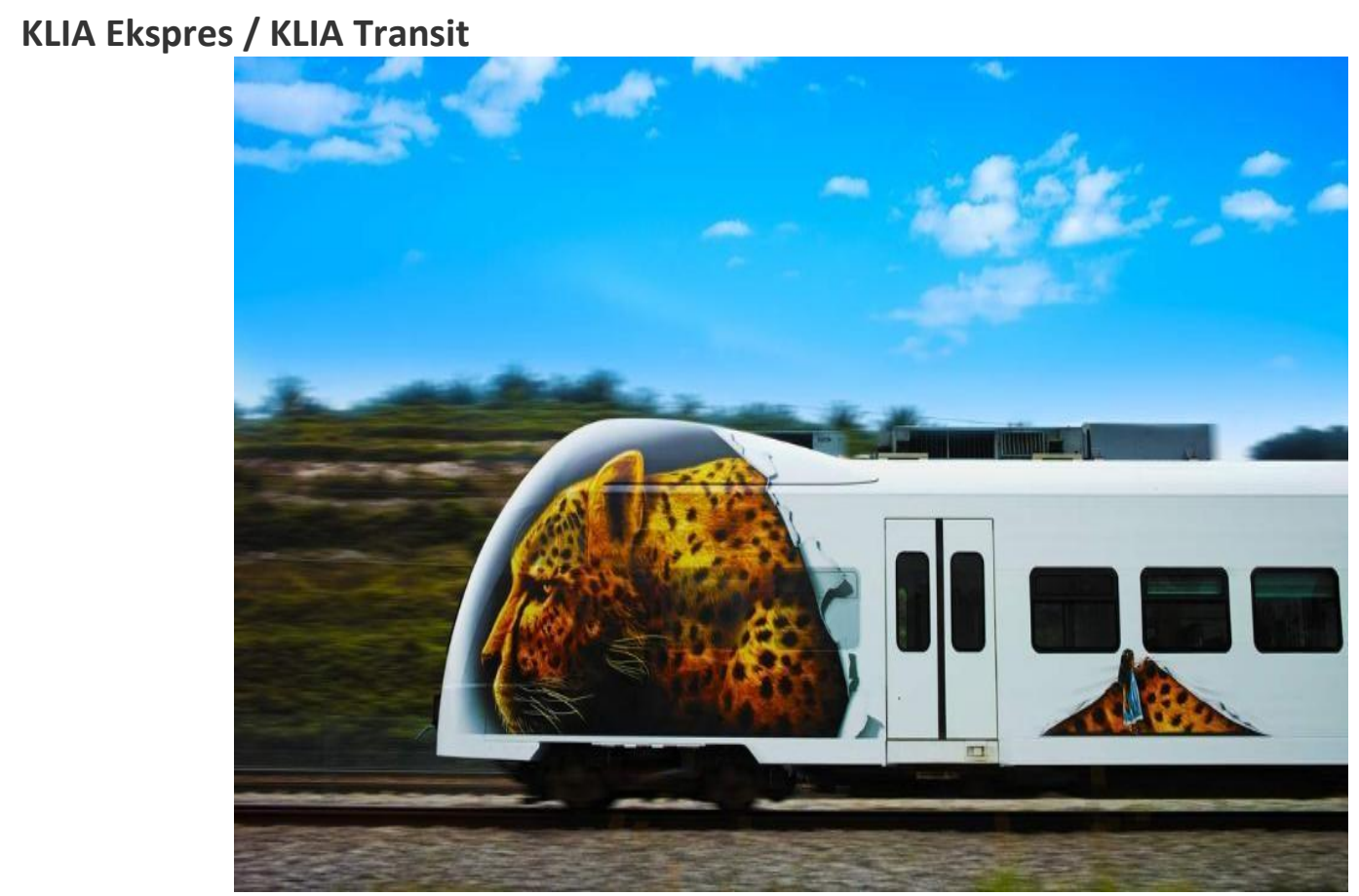

Gambar 6. KLIA Ekspres di Kuala Lumpur(Kumparan, 2019)

Kereta ini sangat nyaman dan dilengkapi dengan fasilitas AC serta WiFi.interior sangat bagus dilengkapi dengan kursi yang nyaman, lampu yang cukup terang. Untuk mendapatkan tiket, dapat menggunakan Vending Machine yang tersedia atau langsung ke loket petugas. Sebenarnya jalur yang digunakan sama, hanya harga tiket-nya lebih mahal yaitu RM. 55. Mode transportasi ini dapat dibedakan menjadi dua, yaitu KLIA Express Airport dan KLIA Transit.Moda transportasi ini ditujukan sebagai transportasi dari dan ke bandara.moda transportasi ini mengambil jalur dari bandara Kuala Lumpur ke bukit bintang. Setelah sampai di KI Sentral, penggunadapat beralih menggunakan KTM, KL Monorail atau LRT.Di Jakarta Hingga saat ini, angkutan massal berbasis rel tersebut masih memiliki tingkat isian atau okupansi penumpang yang cukup rendah. Kereta Bandara Soekarno-Hatta diresmikan Presiden Joko Widodo pada awal tahun 2018, tetapi hingga saat ini moda transportasi massal ini masih belum banyak peminat

\section{LRT (Light Rapid Transit)}

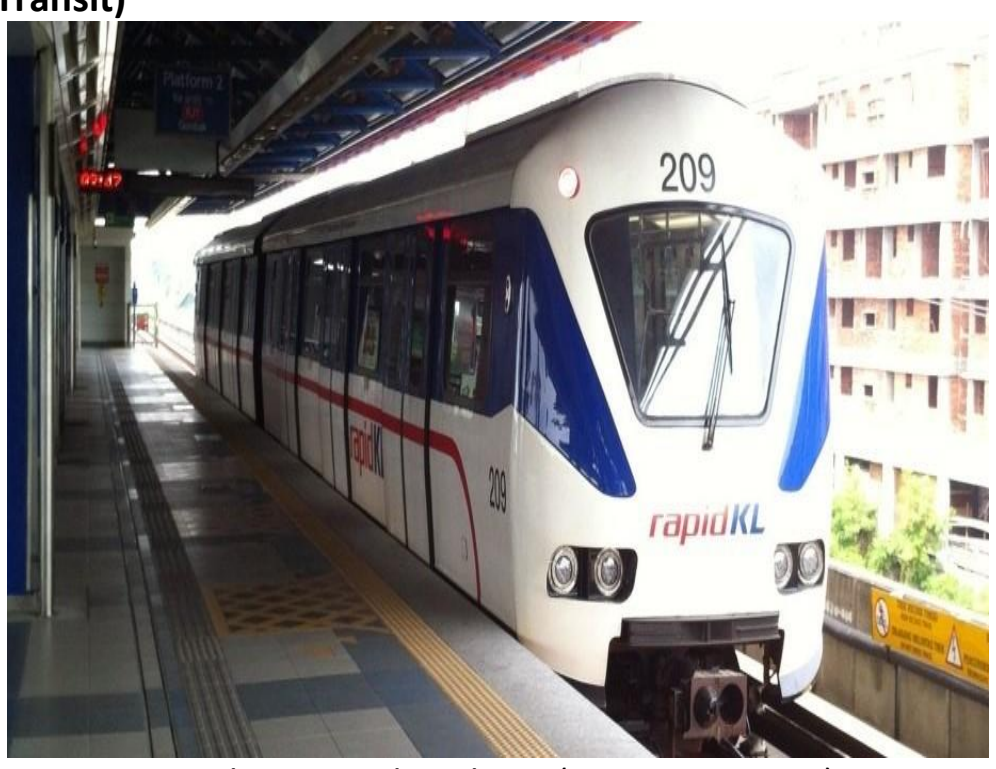

Gambar 7 LRT di Malaysia(Kumparan, 2019) 


\section{2 | MALLOMO: Journal of Community Service}

LRT Malaysia atau yang dikenal juga sebagai Light Rapid Transit masih merupakan bagian dari sistem integrasi Klang Valley Integrated Rail Transit.Moda transportasi ini sedikit berbeda dengan KLMonorail karena memiliki gerbong yang lebih banyak. Selain itu, di LRT juga tersedia dalam dua jalur berbeda yaitu LRT Kelana Jaya merupakan kereta bawah tanah dengan seluruh jalurnya berada di bawah tanah dan jalur Laluan Ampang atau Sri Petaling adalah LRT dengan jalur mengambang atau melayang.Ukuran LRT lebih besar dari monorail dan dapat terdiri dari beberapa gerbong, tempat duduknya tertata rapih dengan tempat duduk yang saling berhadapan. Saat ini jalur LRT dan KLMonorail sudah saling terintegrasi. Untuk mendapatkan tiketnya, dapat menggunakan cara yang sama dengan KL-Monorail. Yaitu dengan token sekali jalan atau kartu Touch $n$ Go (TnG).LRT sudah beroperasi sejak 15 tahun yang lalu, dengan panjang lintasan $29 \mathrm{~km}$ dan jumlah stasiun 24.LRT di Malaysia dikenal dengan nama Rapid KL. Kereta api ringan itu menghubungkan antar daerah di Kota Kuala Lumpur dengan daerah sekitarnya. Lintasan LRT Malaysia tak hanya dibuat melayang (elevated)tetapi juga melintas di bawah tanah. Rapid KL ini terintegrasi dengan moda transportasi lainnnya, seperti Bus, KLIA Ekspress, KLIA transit dan Monorail. Di Jakarta LRT (Lintas Rel Terpadu) digadang-gadang akandipersiapkan menjadi salah satu transportasi umum favorit warga Jakarta. Saat ini, koridor LRT Jakarta sebatas melayani rute Kelapa Gading hingga Velodrome sepanjang 5,8 kilometer, Rencananya, Gubernur DKI Jakarta Anies Baswedan akan membangun rute kereta ringan ini sampai Pasar Tanah Abang, Jakarta Pusat.

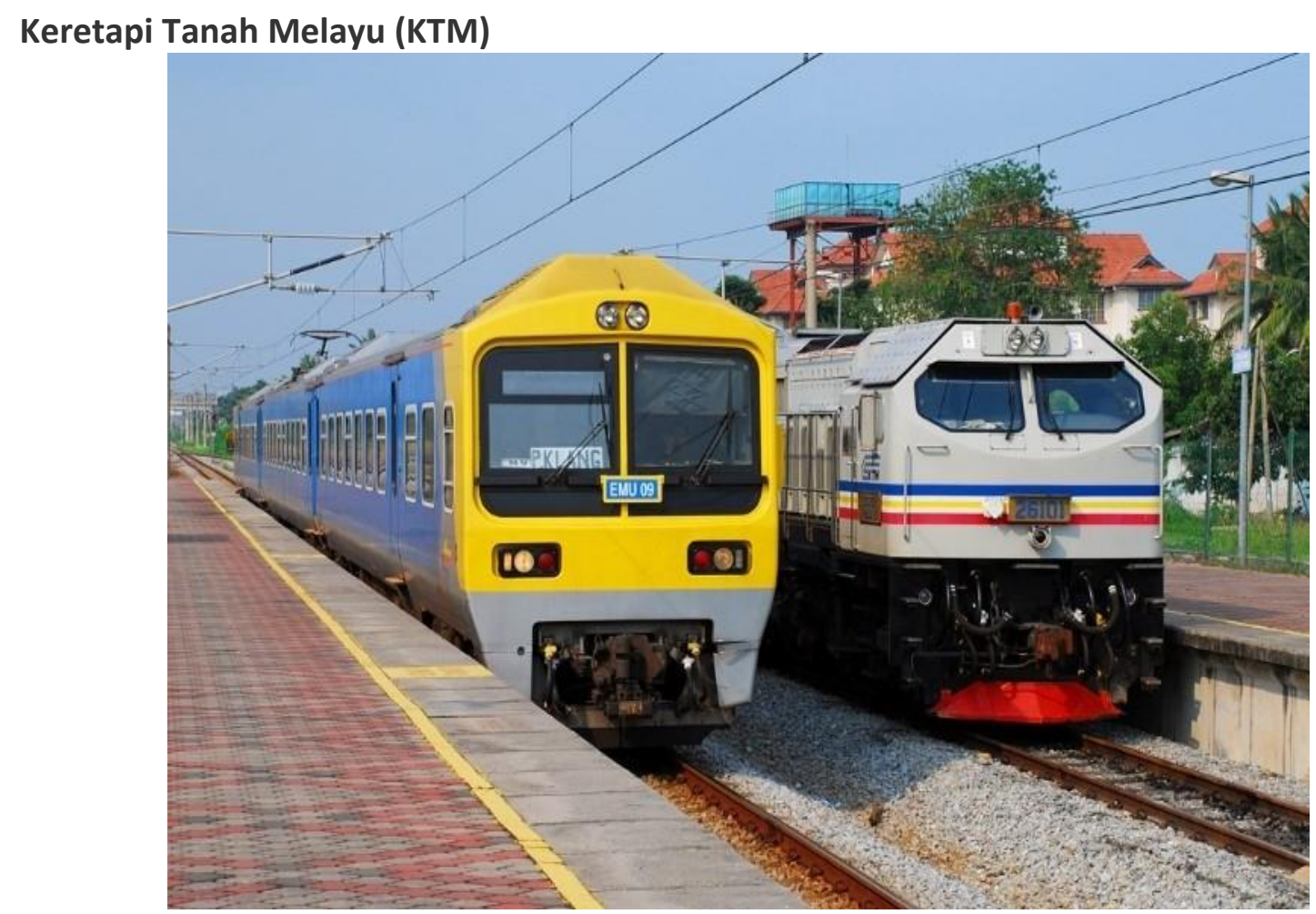

Gambar 8 KTM di Malaysia(Kumparan, 2019)

Moda transportasi lain yang ada di peta dapat menjadi pilihan adalah KTM atau Keretapi Tanah Melayu. Moda transportasi ini merupakan kereta komuter jarak pendek. Dan belum tersambung dengan KL-Monorail atau LRT, sehingga harus keluar stasiun dan dan membeli tiket sendiri lewat Vending Machine atau operator keretapi setempat Selain melayani jarak pendek, model transportasi ini juga menyediakan kereta antar kota.

Salah satu pertimbangan menggunakan moda transportasiini, karena tarifnya yang sangat terjangkau.Dengan pelayanan dan fasilitas yang tidak kalah dengan MRT.Terdapat beberapa pilihan tempat duduk seperti yang saling berhadapan dan berderet seperti kereta pada umumnya. 


\section{Simpulan Dan Saran}

Simpulan

1. Moda transportasi public di Kuala lumpur memiliki tingkat konektifitas yang tinggi, sehingga pengguna jasa dapat merasakan aspek kenyamanan, transparan, efektif, efisien dan terjangkau .

2. Transportasi berbasis rel di Kuala lumpur terintegrasi menjadi satu system yang dikenal dengan Klang Valley Integrated Rail Transit. Moda transportasi tersebut terdiri dari KL Monorail, LRT (light rapid transit), KTM Komuter, KLIA Ekspres / KLIA Transit, dan MRT (Mass Rapid Transit. Sedangkan transportasi berbasis bus seperti Rapid KL dan Go KL.

3. Di bandingkan dengan Jakarta sekarang, transportasi berbasis rel di Kuala lumpur masih lebih maju karena Moda transportasi seperti LRT di Jakarta masih pembangunan dan belum dinikmati masyarakat.

Saran

- Kepada pihak Universitas Muhammadiyah Sidenreng Rappang, program studi banding oleh pasca sarjana ke negara-negara lebih maju merupakan hal positif dan perlu dikembangkan dengan focus berbeda, agar mahasiswa dapat memahami dan didorong untuk mengembangkan hal-hal positif yang dapat diterapkan di Indonesia.

- Kepada Pemerintah Pusat, belajar dari apa yang dilakukan pemerintah kota Guangshou China dan Kuala lumpur Malaysia. Pembangunan infrastruktur jalan Tol dan transportasi berbasis rel yang marak sekarang ini. Perlu dipastikan interkoneksinya antar moda transportasi agar tersedia transportasi public yang murah dan dapat dijangkau masyarakat bawah.

\section{Daftar Rujukan}

Ahmad, J. (2015). Metode Penelitian Administrasi Publik Teori dan Aplikasi. Gava Media.

Amiruddin, A. (Tribun. com. (2019). Mahasiswa Pascasarjana UMS Rappang Lakukan Benchmarking di Malaysia. Retrieved from Tribun.com website:

https://makassar.tribunnews.com/2019/03/14/mahasiswa-pascasarjana-ums-rappang-lakukanbenchmarking-di-malaysia-dan-thailand. Di akses 1 Januari 2020

Dinisan, N. C. (Bisnis. com. (2018). Malaysia Siap Bantu Industri Perkeretaapian Indonesia. Retrieved from Bisnis.com website: https://ekonomi.bisnis.com/read/20181114/98/859664/malaysia-s di akses 31 Des 2019

Fadli; Madani, Muhlis; Idris, M. (Universitas M. M. (2014). Transparansi Pemerintah dalam Pelayanan Sertifikat Tanah di Kota Makassar. Otoritas, IV(2), 101-110.

Kumparan.com. (2017). Commuter Line di Jakarta dan Kuala Lumpur : Serupa tapi Tak Sama. Retrieved from Kumparan website: https://kumparan.com/kumparannews/commuter-line-dijakarta-dan-kuala-lumpur-serupa-tapi-tak- sama di akses 30 des 2019

Kumparan. (2019). Head to Head : Transportasi Jakarta vs Kuala Lumpur. Retrieved from Kumparan.com website: https://kumparan.com/kumparannews/head-to-head-transportasijakarta-vs-kuala-lumpur di akses 31 des 2019

Mustanir, Ahmad;Razak, M. R. . (Fisip-U. M. S. rappang). (2017). Nilai Sosial Budaya Pada Partisipasi Masyarakat Etnik Towani Tolotang Dalam Musyawarah Rencana Pembangunan. Retrieved from http://asosiasipascaptm.or.id/index.php/publikasi/prosiding-konferensi-nasionalappptma-ke-6. Konferensi Nasional Ke-6 Asosiasi Program Pascasarjana Perguruan Tinggi Muhammadiyah Aisyiyah (APPPTMA)

Nursita, S. (2019). Panduan Lengkap Naik MRT Jakarta. Retrieved from Kompos.com website: https://megapolitan.kompas.com/read/2019/07/26/05300001/panduan-lengkap-naik-mrtjakarta-dari-jadwal-sampai-larangan-?page=all. Di akses 31 Des 2019 


\section{4 | MALLOMO: Journal of Community Service}

Pambagio, A. (2013). Protes Publik Transportasi Indonesia. Jakarta: PT. Gramedia Pustaka Utama. Prabowo, D. (Kompas. com. (2019). Idealnya , Panjang Transportasi Berbasis Rel di Jakarta 200 Kilometer. Retrieved from Kompas.com website: https://properti.kompas.com/read/2019/02/15/140000821/idealnya-panjang-transportasiberbasis-rel-di-jakarta-200-kilometer. di akses 31 desember 2019

Razak, M.R.R ; Dahong, Mansyur ; Ahmad, J; Dema, H \& Mustanir, A. (Universitas M. S. (2019). The Effect of Siri' s Marriage on Government Administration. International Journal of Sciences: Basic and Applied Research (IJSBAR), 42(3), 171-184. Retrieved from file://C:/Users/USER/Downloads/New folder/TheEffectofSirisMarriageonGovernmentAdministration.pdf

Razak, M.R.R;Harfiah, S. (Universitas M. S. R. (2018). Partisipasi Masyarakat di Daerah Pegunungan terhadap Perwujudan Good Governance. Akmen Jurnal IImiah, 15(3), 476-486.

Razak, M. R. . (Universitas M. S. R. (2018). Pemanfaatan Teknologi Informasi Dalam Optimalisasi Pelayanan Publik dan Potensi Desa. 1-34. Retrieved from https://www.researchgate.net/publication/331064206_Pemanfaatan_Teknologi_Informasi_Dal am_Optimalisasi_Pelayanan_Publik_dan_Potensi_Desa_Sereang

Sari, N. (Kompas. com. (2019). Panduan Lengkap Naik MRT Jakarta, dari Jadwal sampai Larangan. Retrieved from Kompas.com website: https://megapolitan.kompas.com/read/2019/07/26/05300001/panduan-lengkap-naik-mrtjakarta-dari-jadwal-sampai-larangan-?page=all. Di akses 31 Des 2019

Schefer, J. L. (Wikipedia. com. (2019). Transportasi umum. Retrieved from Wikipedia.com website: https://id.wikipedia.org/wiki/Transportasi_umum\#cite_note-3 di akses 2 Januari 2020

Sodikin, A. (Kompas. com. (2018). Antara Jakarta-Kuala Lumpur, Mengambil Contoh dari Transjakarta. Retrieved from Kompas.com website: https://megapolitan.kompas.com/read/2018/11/28/18245701/antara-jakarta-kuala-lumpurmengambil-contoh-dari-transjakarta?page=all. Di akses 31 Desember 2019

Sugiyono. (2017). MetodePenelitian Administrasi. Publik. Bandung: CV. Alfabeta.

Susilo, M. (bbc I. (2017). Kota impian bagi ekspat : Kuala Lumpur nomor empat, Jakarta nomor 39. Retrieved from bbc.com website: https://www.bbc.com/indonesia/majalah-42057573 di akses 30 des 2019

Tech, K. (2018). Berita Logistik dan Transportasi. In Kargo Tech. Retrieved from https://kargo.tech/artikel/cara-pendaftaran-uji-kir-kendaraan-mobil-dan-truk/ di akses 31 Des 2019 